\title{
Flagellin gene and protein variation amongst clinical isolates of Pseudomonas aeruginosa
}

\author{
Craig Winstanley, ${ }^{1}$ Melanie A. Coulson, ${ }^{1}$ Beatrix Wepner, ${ }^{1}$ \\ J. Alun W. Morgan ${ }^{2}$ and Charles A. Hart ${ }^{3}$
}

Author for correspondence: Craig Winstanley. Tel. +44 1203838 246. Fax: + 441203838282.
e-mail: apx086@coventry.ac.uk

1 Biosciences, School of Natural and Environmental Sciences, Coventry University, Priory Street, Coventry CV1 5FB, UK

2 Horticulture Research International,

Wellesbourne,

Warwickshire CV35 9EF UK

3 Department of Medical Microbiology, Royal Liverpool University Hospital, Liverpool L7 8XP, UK

\begin{abstract}
Flagellin gene sequences from 64 clinical isolates of the opportunistic pathogen Pseudomonas aeruginosa were amplified by PCR and subjected to RFLP analysis by using seven restriction enzymes to digest the amplified products. Using this approach the isolates were assigned to one of 13 groups. The method was rapid, reproducible and applicable to all isolates. In contrast, serotyping failed to satisfactorily resolve $49 \%$ of the strains tested. The vast majority of clinical isolates generated amplified products of $1.02 \mathrm{~kb}$ (type a) or $1.25 \mathrm{~kb}$ (type b). Electron microscopical analysis revealed evidence for some flagellar structural variation between $P$. aeruginosa strains. This study provides further evidence that the flagellin gene is a widely applicable and useful genetic marker for studying genetic variation within populations of closely related bacteria.
\end{abstract}

Keywords: Pseudomonas aeruginosa, flagellin, PCR, genetic diversity, typing

\section{INTRODUCTION}

Pseudomonas aeruginosa is an important opportunistic pathogen, often being associated with high mortality in patients with cancer, burn wounds, organ transplants and cystic fibrosis (CF) (Bodey et al., 1983). To identify environmental sources of the pathogen, and to gain an indication of whether transmission of strains has occurred between patients, there is a need for methods to detect, identify and differentiate between pseudomonads that can act as opportunistic pathogens. There have been a number of approaches to typing $P$. aeruginosa (International Pseudomonas aeruginosa Typing Study Group, 1994; Picard et al., 1994; Elaichouni et al., 1994; Grattard et al., 1994). Serotyping and pyocin typing, often used in combination, are the most widely employed methods, with a commercially available kit (Rougier Biotech) allowing the assignment of a strain to one of 17 O-serotype groups using slide agglutination tests involving monoclonal antibodies. In a major study, other typing methods, including RFLP of total DNA, phage typing and pilin gene typing using gene probes, have been compared with the common methods to assess reproducibility and typeability (International Pseudomonas aeruginosa Typing Study Group, 1994). The methods differed in both their reproducibility and their capacity to identify unique typing patterns. RFLP of total DNA and pilin gene typing methods were the most reproducible, with RFLP also identifying the largest number of groups. The authors concluded that RFLP of total DNA appears to be the best typing method for $P$. aeruginosa with rough LPS obtained from patients with CF, whereas LPS serotyping, which is much simpler, is best in other cases. Other DNA-based methods used to differentiate between strains of $P$. aeruginosa include arbitrarily primed PCR (Elaichouni et al., 1994; Grundmann et al., 1994) and ribotyping using different restriction enzymes (Grattard et al., 1994). A recent report compared three DNA-based typing techniques and commented favourably on their discriminatory power (Grundmann et al., 1995).

Flagella, consisting of flagellin filament, hook and basal body, are responsible in pseudomonads for bacterial motility, which has been implicated as an invasive virulence factor in $P$. aeruginosa (Drake \& Montie, 1988). Flagellum filaments are also a source of vaccine for active or passive immunization (Drake \& Montie, 1987). Variation in flagellin size has been reported in $P$. aeruginosa where two distinct flagellin protein antigenic types are found (Allison et al., 1985; Kelly-Wintenberg \& Montie, 1989). Allison et al. (1985) compared the sizes of flagellin proteins from a limited number of strains of $P$. aeruginosa representing the two major groups of flagellar antigen types. Type b strains had flagellins with a molecular mass of $53 \mathrm{kDa}$. Type a strains were reported as more heterogeneous with molecular masses ranging from $45 \mathrm{kDa}$ to $52 \mathrm{kDa}$. A type a flagellin gene has been cloned and sequenced (Totten \& Lory, 1990). In another study, 
flagellin genes from two Pseudomonas putida strains (PaW8 and PRS2000) were cloned and sequenced (Winstanley et al., 1994). The P. putida PaW8 and PRS2000 flagellin genes share considerable homology with other sequenced flagellin genes at the $\mathrm{N}$-terminal and $\mathrm{C}$-terminal ends, with the closest available relative, $P$. aeruginosa (Totten \& Lory, 1990), showing the greatest homology. Sequence analysis has shown that variation is most apparent in the central region of the flagellin protein. Indeed the antigenic target of a monoclonal antibody that is specific for the flagellin of P. putida PaW8 (MLV1; Morgan et al., 1991) is located in this central variable region (Winstanley et al., 1994).

By comparing the flagellin gene sequences of the two $P$. putida strains and the previously published $P$. aeruginosa strain, it was possible to design oligonucleotide primers specific for N-terminal (CW46) and C-terminal (CW45) conserved regions. Using these primers, the central variable region of the flagellin gene from a number of different species of ribosomal RNA group I pseudomonads (Schleifer, 1994) can be amplified by using PCR (unpublished data). Flagellin gene size, restriction enzyme cutting site polymorphisms and DNA sequencing can then be used to differentiate between strains. In this paper we describe the use of PCR amplification of flagellin genes coupled with RFLP analysis as a method for differentiating between clinical isolates of $P$. aeruginosa, including a number of isolates from cystic fibrosis patients.

\section{METHODS}

Bacterial strains and serotyping. With the exception of the type strain NCIB 8295, the bacterial strains used in this study, listed in Table 1, are clinical isolates obtained at the Royal Liverpool Hospital. They include 28 strains (names prefixed with $\mathrm{K}, \mathrm{C}$ or $\mathrm{D}$ ) isolated from children suffering from cystic fibrosis, urinary tract infection, bacteraemia and meningitis, several of which are mucoid. All strains were identified as $P$. aeruginosa using the API-NE (BioMérieux) test. Strains were maintained on nutrient agar and grown at $37^{\circ} \mathrm{C}$. Serotyping was carried out at the Central Public Health Laboratories, Colindale, London.

PCR amplification. Oligonucleotide primers CW45 (GGCAGCTGGTTNGCCTG) and CW46 (GGCCTGCAGATCNCCAA) were obtained from Genosys (Cambridge). Cells taken from a nutrient agar plate were suspended in sterile distilled water containing $5 \mathrm{mM}$ EDTA and boiled for $5 \mathrm{~min}$. One microlitre of this lysed suspension was used directly in a standard amplification mixture. Amplifications were carried out in $50 \mu \mathrm{l}$ volumes containing 2 units DynaZyme (Flowgen Instruments), $200 \mathrm{nM}$ of each primer (CW45 and CW46), 1× DynaZyme buffer and $100 \mu \mathrm{M}$ nucleotides (dATP, dCTP, dGTP, dTTP). Amplifications were carried out in a MiniCycler (Genetic Research Instrumentation) for 30 cycles consisting of $95^{\circ} \mathrm{C}(40 \mathrm{~s}), 55^{\circ} \mathrm{C}(1 \mathrm{~min})$ and $72{ }^{\circ} \mathrm{C}(2 \mathrm{~min})$, with an additional extension time at $72^{\circ} \mathrm{C}(10 \mathrm{~min})$ after the 30 cycles were completed. A hot start approach was used, with the lysed suspension (containing target DNA) added last as the other ingredients were held at $94{ }^{\circ} \mathrm{C}$. After amplification, $5 \mu \mathrm{l}$ samples were subjected to electrophoresis on a standard $0.7 \%$ agarose gel to confirm the presence of amplified products.

Restriction digestion of amplified products. Samples $(5 \mu \mathrm{l})$ of amplified products were digested with the restriction enzymes
MboI, TaqI, MspI, HaelII, CfoI, RsaI and SalI using the conditions recommended by the supplier (Life Technologies). These digests were then subjected to electrophoresis on 2-3\% (w/v) MetaPhor agarose gels (Flowgen) using PCR Size Marker (AMS Biotechnology) as a standard size marker (fragment sizes: $50,150,300,500,750,1000,1500$ and $2000 \mathrm{bp}$ ).

Flagellin protein isolation. Flagellin proteins were isolated by the procedure described by Brett et al. (1994), using $15 \%(\mathrm{w} / \mathrm{v})$ ammonium sulphate for precipitation of the protein, and analysed on SDS-PAGE gels $(10 \%, \mathrm{w} / \mathrm{v}$, acrylamide). SDS- $6 \mathrm{H}$ (Sigma) was used for molecular mass markers.

Glycoprotein detection. After separation of flagellin proteins by SDS-PAGE, glycoprotein detection was carried out both by direct gel staining using Schiff's reagent (Sigma) according to the manufacturer's recommendations, and by using the DIG Glycan Detection kit (Boehringer) on proteins transferred by Western blotting to nitrocellulose filters.

Electron microscopy. Cells were grown overnight on nutrient broth containing $0.3 \%$ agar No.1 (Oxoid). Formvar-coated copper grids were placed face down on the cell growth and then air-dried. The samples were stained with $1 \%(\mathrm{w} / \mathrm{v})$ phosphotungstic acid ( $\mathrm{pH} \mathrm{6.0)}$ for 1 min, air-dried and observed under a JEOL 1100CXII transmission electron microscope. For flagella width measurements, the widths of three flagella from one area of a grid were measured three times each. This was repeated in two additional areas of the grid. Mean width and standard error $(n=27)$ were calculated.

\section{RESULTS AND DISCUSSION}

\section{PCR amplification of $P$. aeruginosa flagellin genes}

PCR amplification using oligonucleotide primers CW45 and CW46 gave single amplified products from all 64 clinical isolates of $P$. aeruginosa tested. All but one of the isolates gave products of either $1.02 \mathrm{~kb}$ (type a; 37 isolates) or $1.25 \mathrm{~kb}$ (type b; 26 isolates). Flagellin proteins from representatives of each type were isolated and analysed (Fig. 1). This confirmed the previous observation (Allison et al., 1985) that type b strains produce larger flagellin proteins with a molecular mass of approximately $53 \mathrm{kDa}$ whereas type a strains produce smaller flagellins that are more variable in size. Analysis of flagellin gene sequence data from the previously sequenced type a flagellincontaining strain $P$. aeruginosa PAK (Totten \& Lory, 1990) suggested that this strain would yield an amplified product of $1.02 \mathrm{~kb}$. All the evidence from gene and protein size therefore suggests strongly that type a and type b strains (as previously defined by flagellin protein size) can be differentiated on the basis of PCR-amplified product size.

\section{RFLP analysis of flagellin gene amplified products}

Fig. 2 shows the different restriction patterns obtained from the flagellin gene amplified products of the 64 clinical isolates. Type $b$ isolates could be further divided into four sub-groups (I-IV) by restriction site variation. Type a isolates could be subdivided into eight subgroups (V-XII). Strain K979 exhibited a larger amplified product, thus forming an additional group and making a total of 13 groups in all (Table 1). The RFLP types 
$P$. aeruginosa flagellin genes and proteins

Table 1. P. aeruginosa strains used in this study

\begin{tabular}{|c|c|c|c|}
\hline Group* & Strain & Source/description & Serotype $\ddagger$ \\
\hline \multirow[t]{10}{*}{ I } & E35.93 & Clinical isolate & PA \\
\hline & C201 & Isolated from blood & OII \\
\hline & C269 & $\mathrm{CF}$ isolate & PA \\
\hline & $\mathrm{C} 270$ & $\mathrm{CF}$ isolate & $\mathrm{PA}$ \\
\hline & C536 & CF isolate & OII \\
\hline & C537 & $\mathrm{CF}$ isolate & OII \\
\hline & $\mathrm{C} 540$ & CF isolate & ND \\
\hline & C541 & $\mathrm{CF}$ isolate & NT \\
\hline & C594 & Isolated from urine; mucoid & PA \\
\hline & C758 & Isolated from urine; mucoid & NT \\
\hline \multirow[t]{9}{*}{ II } & $\mathrm{D} 27$ & Isolated from blood & PA \\
\hline & $\mathrm{BC} 5736 \mathrm{~T}$ & Clinical isolate & NT \\
\hline & 375 & Clinical isolate & OII \\
\hline & 409 & Clinical isolate & O1 \\
\hline & 932 & Clinical isolate & $\mathrm{O} 8$ \\
\hline & E32.93 & Clinical isolate & $\mathrm{O} 10$ \\
\hline & E38.93 & Clinical isolate & OII \\
\hline & C221 & Isolated from cerebrospinal fluid & ND \\
\hline & C618 & Isolated from urine; mucoid & $\mathrm{ND}$ \\
\hline \multirow[t]{6}{*}{ III } & 593 & Clinical isolate & OII \\
\hline & E20.92 & Clinical isolate & ND \\
\hline & C646 & Isolated from urine; mucoid & PA \\
\hline & C647 & Isolated from urine; mucoid & OII \\
\hline & C659 & Isolated from urine; mucoid & OII \\
\hline & C945 & Isolated from urine; mucoid & PA \\
\hline IV & $\mathrm{E} 41.93$ & Clinical isolate & PA \\
\hline \multirow[t]{20}{*}{$\mathrm{V}$} & NCIB & Type strain & O6 \\
\hline & 8295 & & \\
\hline & 390 & Clinical isolate & $\mathrm{O} 1$ \\
\hline & 512 & Clinical isolate & $\mathrm{O} 1$ \\
\hline & 524 & Clinical isolate & ND \\
\hline & 585 & Clinical isolate & PA \\
\hline & K524 & Isolated from blood & OII \\
\hline & K654 & Isolated from blood & OHI \\
\hline & $\mathrm{K} 719 \mathrm{a}$ & Isolated from blood & O6 \\
\hline & $\mathrm{K} 719 \mathrm{~b}$ & Isolated from blood & O6 \\
\hline & $\mathrm{K} 783$ & Isolated from peritoneal fluid & $\mathrm{O} 10$ \\
\hline & K933 & Isolated from blood & PA \\
\hline & $\mathrm{E} 8.92$ & Clinical isolate & NT \\
\hline & E10.92 & Clinical isolate & $\mathrm{O} 11$ \\
\hline & E13.93 & Clinical isolate & $\mathrm{O} 15$ \\
\hline & $\mathrm{E} 24.93$ & Clinical isolate & NT \\
\hline & E35.92 & Clinical isolate & O1 \\
\hline & $\mathrm{E} 50.93$ & Clinical isolate & PA \\
\hline & C195 & Isolated from urine & OII \\
\hline & C655 & Isolated from urine; mucoid & PA \\
\hline \multirow[t]{9}{*}{ VI } & 391 & Clinical isolate & $\mathrm{PA}$ \\
\hline & 534 & Clinical isolate & $\mathrm{O} 4$ \\
\hline & 547 & Clinical isolate & O5 \\
\hline & 557 & Clinical isolate & $\mathrm{ND}$ \\
\hline & E12.92 & Clinical isolate & PA \\
\hline & E22.93 & Clinical isolate & ND \\
\hline & $\mathrm{E} 29.92$ & Clinical isolate & PA \\
\hline & $\mathrm{E} 52.92$ & Clinical isolate & O9 \\
\hline & C584 & Isolated from blood & PA \\
\hline
\end{tabular}

\begin{tabular}{|llll|}
\hline Group* & Strain & Source/description $\dagger$ & Serotype $\neq$ \\
\cline { 1 - 3 } VII & 597 & Clinical isolate & O11 \\
& K664 & Isolated from lung & O11 \\
& E13.92 & Clinical isolate & O6 \\
& E46.92 & Clinical isolate & NT \\
VIII & 639 & Clinical isolate & PA \\
& 658 & Clinical isolate & PA \\
IX & 434 & Clinical isolate & PA \\
X & 590 & Clinical isolate & PA \\
XI & K701 & CF isolate; mucoid & PA \\
XII & 546 & Clinical isolate & O3 \\
XIII & K979 & CF isolate; mucoid & PA \\
\hline
\end{tabular}

* Flagellin gene RFLP group as defined in Table 2.

†CF, cystic fibrosis.

$\ddagger$ ND, Not determined; NT, not typable (no agglutination); PA, polyagglutinable.

obtained indicate that type a flagellin gene sequences are more variable than type $b$, an observation which is consistent with the variation found amongst flagellin protein molecular masses. Table 2 summarizes the distribution of the clinical isolates amongst the flagellin gene RFLP groups (I-XIII).

\section{Comparison with serotyping}

A significant proportion of the clinical isolates tested ( 28 out of $57 ; 49 \%$ ) were either polyagglutinable or nontypable. O-serotyping of the remaining 29 isolates revealed that representatives of 11 serotype groups were present (Table 1). There was no significant correlation between flagellin gene group and serotype group. The most common serotype group, OII (11 strains), could be subdivided into four sub-groups by flagellin gene variation whilst the most common flagellin gene group, V (18 strains), could be subdivided into six sub-groups by serotyping.

The method described in this paper relies on the amplification of flagellin gene sequences from strains of $P$. aeruginosa. Flagellin gene amplified products were obtained from all $P$. aeruginosa isolates screened and the procedure was highly reproducible $(100 \%)$. The whole process can be completed in 5-6 h and is considerably more effective than serotyping, which leads to inconclusive results for a significant proportion of $P$. aeruginosa clinical isolates screened. The method requires relatively simple equipment and procedures, and is rapid and reproducible, although less able to distinguish between strains than some alternative DNA-based methods (Grundmann et al., 1994). It may be best applied in combination with other methods or as an initial screening procedure. 


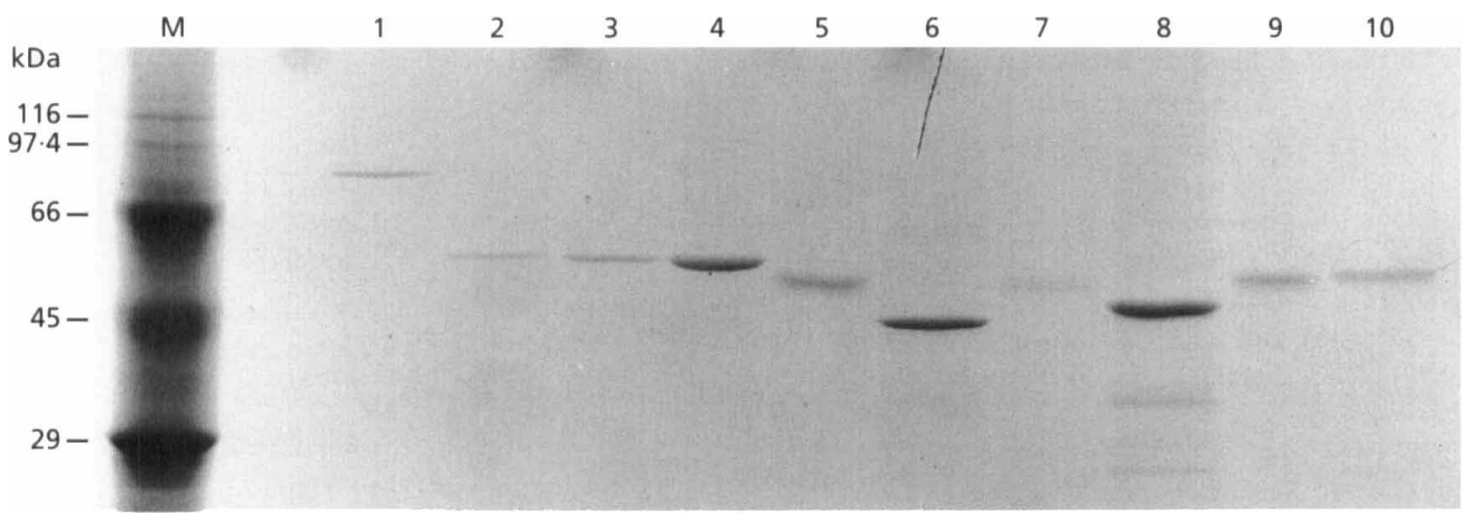

Fig. 1. PAGE of $P$. aeruginosa flagellins. SDS-PAGE gel $(10 \%, w / v$, acrylamide) containing flagellin proteins isolated from strains K979 (lane 1), E20.92 (lane 2), 593 (lane 3), C536 (lane 4), 597 (lane 5), 547 (lane 6), K701 (lane 7), E13.92 (lane 8), K664 (lane 9) and 546 (lane 10). Lane 1 contains a large flagellin isolated from strain K979 which also yields an unusually large flagellin gene amplified product. Lanes 2,3 and 4 contain type b flagellins (no size variation). Lanes $5-10$ contain type a flagellins (size variation apparent). Lane $M$ contains molecular mass markers.

(a)

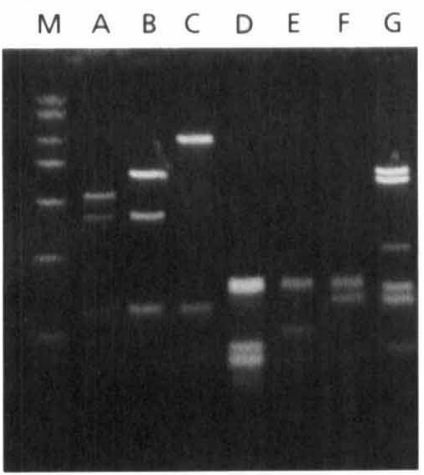

(d)

(e) (b)

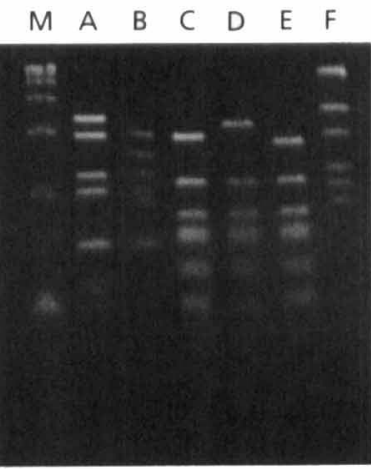

$(f)$
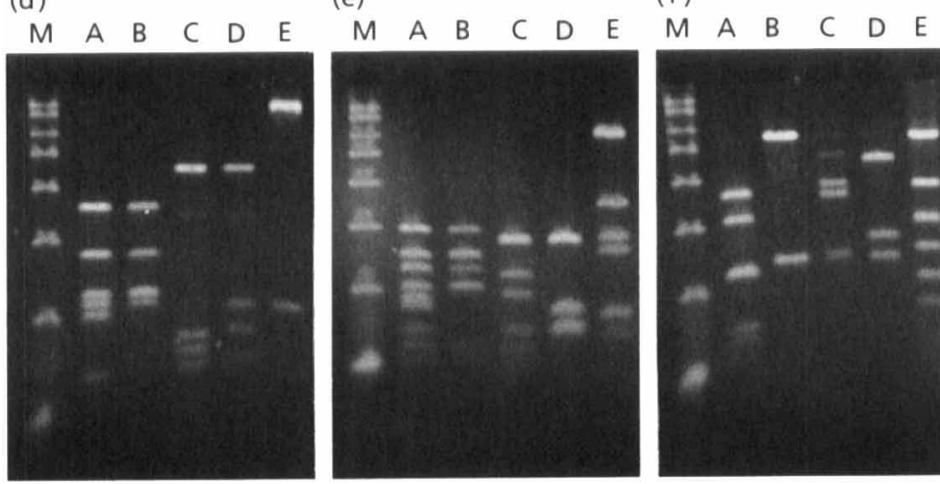

\section{$M A B C D E$}

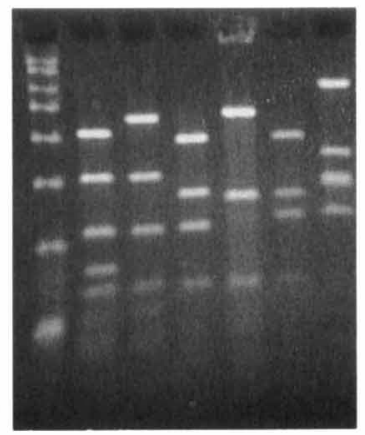

(g)
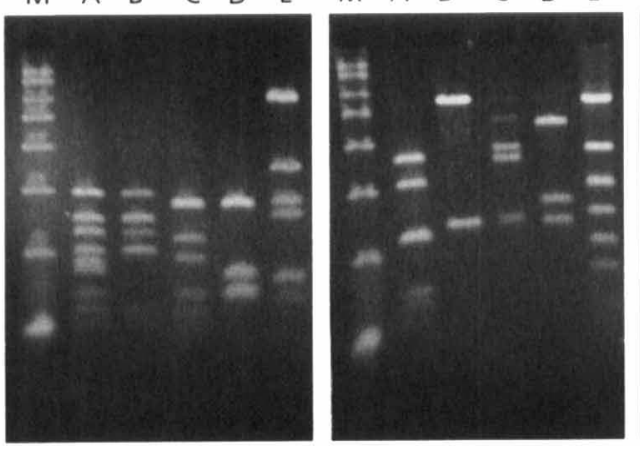

$M \quad A \quad B \quad C \quad D$

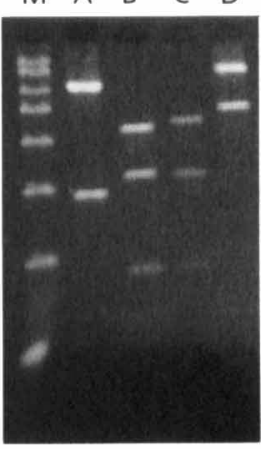

Fig. 2. RFLP patterns of $P C R$-amplified $P$. aeruginosa flagellin genes. The gels show the different patterns generated after digestion of amplified products with Mbol (a), Taql (b), Mspl (c), Haelll (d), Cfol (e), Rsal (f) and Sall (g). In each case lane $M$ contains PCR marker DNA. Other lanes contain RFLP patterns A, B, C, D, E, F and G as applicable to each particular restriction enzyme and as referred to in Table 2.

\section{Variation amongst flagellin genes and proteins}

Flagellin gene amplified product length separated all but one of the $64 P$. aeruginosa isolates into two major homogeneous groups. The homogeneity in flagellin gene size of the two major groups suggests that flagellin protein post-translational modification may be causing the variation in the size of type a flagellin proteins reported previously and observed in this study (Fig. 1) (Allison et al., 1985). Although flagellin gene amplified products do not represent the whole coding sequence, the missing terminal sequences (approximately $27 \mathrm{C}$-terminal bp and $57 \mathrm{~N}$-terminal bp) are in regions where no significant variation in length is apparent even when 
Table 2. Distribution of $P$. aeruginosa isolates amongst flagellin gene RFLP groups

\begin{tabular}{|c|c|c|c|c|c|c|c|c|c|}
\hline \multirow{2}{*}{$\begin{array}{l}\text { RFLP } \\
\text { Group }\end{array}$} & \multirow{2}{*}{$\begin{array}{l}\text { No. of } \\
\text { strains }\end{array}$} & \multirow{2}{*}{$\begin{array}{c}\text { PCR product } \\
(\mathrm{kb})\end{array}$} & \multicolumn{7}{|c|}{ Restriction enzyme patterns generated* } \\
\hline & & & MboI & TaqI & $M s p \mathrm{I}$ & HaeIII & CfoI & RsaI & SalI \\
\hline I & 10 & $1 \cdot 25$ & A & A & A & A & A & A & A \\
\hline II & 9 & $1 \cdot 25$ & $\mathrm{~B}$ & A & A & $\mathrm{A}$ & A & A & A \\
\hline III & 6 & $1 \cdot 25$ & A & A & B & A & A & A & A \\
\hline IV & 1 & $1 \cdot 25$ & $\mathrm{C}$ & $\mathrm{B}$ & A & $\mathrm{B}$ & $\mathrm{B}$ & A & A \\
\hline V & 18 & $1 \cdot 02$ & $\mathrm{D}$ & C & C & C & C & B & B \\
\hline VI & 9 & $1 \cdot 02$ & $\mathrm{D}$ & $\mathrm{D}$ & C & C & C & B & C \\
\hline VII & 4 & 1.02 & $\mathrm{E}$ & $\mathrm{E}$ & $D$ & C & $\mathrm{D}$ & C & B \\
\hline VIII & 2 & $1 \cdot 02$ & $\mathrm{D}$ & C & C & C & C & B & C \\
\hline IX & 1 & $1 \cdot 02$ & $\mathrm{D}$ & C & C & C & C & $\mathrm{D}$ & B \\
\hline $\mathrm{X}$ & 1 & 1.02 & $\mathrm{D}$ & C & C & $\mathrm{D}$ & $\mathrm{C}$ & $\mathrm{D}$ & $\mathrm{B}$ \\
\hline XI & 1 & $1 \cdot 02$ & $\mathrm{E}$ & C & $\mathrm{E}$ & C & $\mathrm{D}$ & C & B \\
\hline XII & 1 & $1 \cdot 02$ & $\mathrm{~F}$ & $\mathrm{E}$ & $\mathrm{D}$ & C & $\mathrm{D}$ & $\mathrm{C}$ & $\mathrm{B}$ \\
\hline XIII & 1 & $\approx 2$ & $G$ & $\mathrm{~F}$ & $\mathrm{~F}$ & $\mathrm{E}$ & $E$ & $\mathrm{E}$ & $\mathrm{D}$ \\
\hline
\end{tabular}

* Restriction enzyme patterns are shown in Fig. 2.

flagellin genes from very different bacterial species are aligned. This suggests that the variation in type a flagellin protein size is unlikely to be due to variation outside the amplified region. Totten \& Lory (1990) reported a difference between the predicted molecular mass $(40 \mathrm{kDa})$ and the molecular mass estimated by SDS-PAGE $(45 \mathrm{kDa})$ for the type a flagellin of strain PAK. Posttranslational modifications have been observed with other bacterial flagellins (Joys \& Kim, 1978; Logan et al., 1989; Wieland et al., 1985). Indeed, Kelly-Wintenberg et al. $(1990,1993)$ reported the presence of phosphorylated tyrosines in the flagellin of $P$. aeruginosa PAO and other strains. However, the size discrepancy between predicted and observed molecular masses is greater than could be accounted for by phosphorylation of tyrosines alone. We investigated the possibility that $P$. aeruginosa flagellins may be glycoproteins by direct gel staining and by using the DIG Glycan Detection kit, but found no evidence for this.

The assignment of the vast majority of $P$. aeruginosa isolates into one of two flagellar types resembles the flagellin phase variation exhibited by Salmonella typhimurium, with the important difference that no switching between flagellin types has been observed in $P$. aeruginosa, which contains only one copy of the flagellin gene. There is considerable evidence that the two flagellar types are quite distinct. Restriction digest patterns and preliminary sequence data (unpublished) suggest that the two major flagellin groups of $P$. aeruginosa form separate evolutionary groups, thus excluding the possibility that type a flagellin is simply a deleted version of type b flagellin. Type a flagellins also differ from type $b$ in their apparent tendency to undergo post-translational modification, a property which introduces an additional source of variability.

There was no clear correlation amongst type a flagellins between RFLP group and protein molecular mass. It was possible to find members of the same RFLP group that varied in approximate molecular mass between $45 \mathrm{kDa}$ and $50 \mathrm{kDa}$, which represents the entire range found amongst the type a flagellins analysed in this study. An example of this variation can be seen in Fig. 1 between two strains of RFLP group VII (lanes 5 and 8). In addition, flagellin proteins with similar approximate molecular masses were found in a range of RFLP groups. Any meaningful correlation between DNA sequence variation and protein molecular mass will have to be carried out using complete DNA sequences rather than restriction site variation.

Electron microscopical analysis of flagellar preparations revealed variations in the width of flagella between representative strains of type b (strain C201, width $17 \cdot 35 \pm 0 \cdot 12 \mathrm{~nm}$; strain 409 , width $17 \cdot 46 \pm 0 \cdot 3 \mathrm{~nm}$ ) and type a (strain 590 , width $16.9 \pm 0.3 \mathrm{~nm}$ ). P. aeruginosa strain K979, which contains an unusually large flagellin gene of $\approx 2 \mathrm{~kb}$, had a flagellar width of $17 \cdot 15 \pm 0 \cdot 18 \mathrm{~nm}$ with flagella appearing speckled instead of lined as is the case with type a and type b flagella (Fig. 3). These preliminary electron microscope studies suggest some flagellar structural variation amongst clinical isolates of $P$. aeruginosa that merits further investigation. Further sequence data are being collected and analysed to gain an insight into the molecular basis of such structural variation and to assess the mechanism of antigenic diversity among $P$. aeruginosa flagellins.

Flagellin gene sequences have been used to study diversity in other bacterial systems. In Eschericbia coli (Schoenhals \& Whitfield, 1993) it has been reported that the relative sizes of the conserved N-terminal and conserved Cterminal regions reflect the relatedness of E. coli flagellins. Alignment of the first 190 and the last 100 amino acids was used to study flagellin protein sequence relatedness. Masten \& Joys (1993) sequenced a number of flagellin 

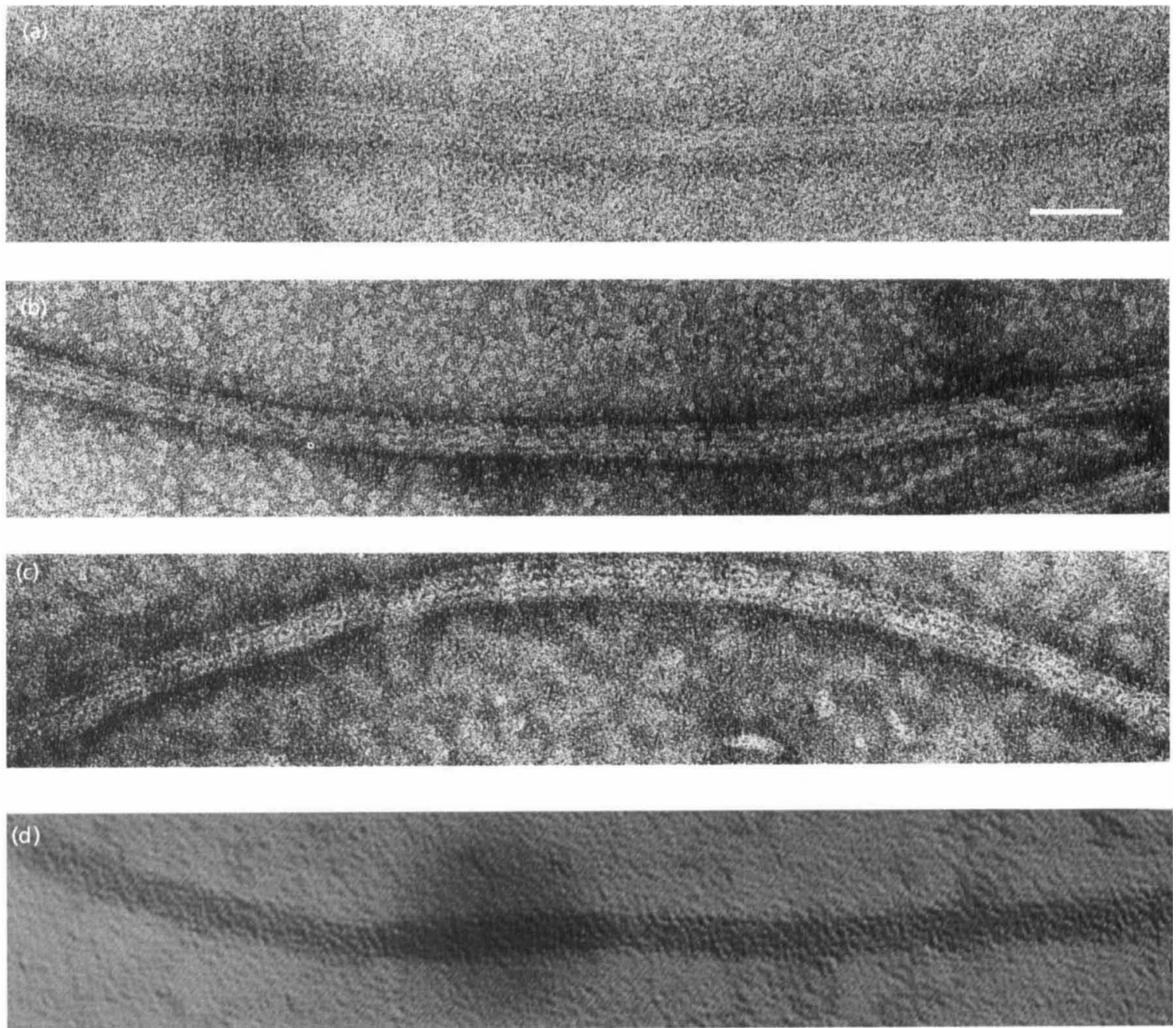

Fig. 3. Electron microscopical analysis of $P$. aeruginosa flagellar preparations. TEM analysis of flagellar preparations from strains C201 (type b flagellin) (a), 409 (type b flagellin) (b), 590 (type a flagellin) (c) and K979 (unusually large flagellin) (d) are shown. Bar, $20 \mathrm{~nm}$. All samples were stained in an identical manner. The electron micrographs illustrate the greatest contrast of flagella structure obtained. This has resulted in differences in the background.

genes from Salmonella spp. in order to study evolutionary relatedness and identify epitope sites for $g$ antigen flagellins. In Campylobacter coli and Campylobacter jejuni Alm et al. (1993) studied RFLPs of amplified flagellin genes to study the genetic diversity among serogroups. The flagellin gene has also been shown to serve as a sensitive and specific target gene for PCR detection of $C$. coli and $C$. jejuni in environmental water samples (Oyofu \& Rollins, 1993). This study further confirms that the flagellin gene is a widely applicable and useful genetic marker for studying genetic variation within populations of closely related bacteria.

\section{ACKNOWLEDGEMENTS}

This work was supported by an award to C.W. from the Nuffield Foundation and by the Biotechnology and Biological Sciences Research Council. We would like to thank Tyrone L. Pitt (Central Public Healthı Laboratory, Colindale Avenue,
London) for the serotyping of strains, and Jim Justice and Colin Clay for conducting the electron microscope work.

\section{REFERENCES}

Allison, J. S., Dawson, M., Drake, D. \& Montie, T. C. (1985). Electrophoretic separation and molecular weight characterization of Pseudomonas aeruginosa $\mathrm{H}$-antigen flagellins. Infect Immun 49, 770-774.

Alm, R. A., Guerry, P. \& Trust, T. J. (1993). Distribution and polymorphism of the flagellin genes from isolates of Campylobacter coli and Campylobacter jejuni.J Bacteriol 175, 3051-3057.

Bodey, G. P., Bolivar, R., Feinstein, V. \& Jadeja, L. (1983). Infections caused by Pseudomonas aeruginosa. Rev Infect Dis 5, 279-293.

Brett, P. J., Mah, D. C. W. \& Woods, D. E. (1994). Isolation and characterization of Pseudomonas pseudomallei flagellin proteins. Infect Immun 62, $1914-1919$.

Drake, D. \& Montie, T. C. (1987). Protection against Pseudomonas 
aeruginosa infection by passive transfer of antiflagellar serum. Can J Microbiol 33, 755-763.

Drake, D. \& Montie, T. C. (1988). Flagella, motility and invasive virulence of Pseudomonas aeruginosa. J Gen Microbiol 134, 43-52.

Elaichouni, A., Verschraegen, G., Claeys, G., Devleeschouwer, M., Godard, C. \& Vaneechoutte, M. (1994). Pseudomonas aeruginosa serotype $\mathrm{O} 12$ outbreak studied by arbitrary primer PCR. J Clin Microbiol 32, 666-671.

Grattard, F., Pozetto, B., Ros, A. \& Gaudin, O. G. (1994). Differentiation of $P$ seudomonas aeruginosa strains by ribotyping: high discriminatory power by using a single restriction endonuclease. $J$ Med Microbiol 40, 275-281.

Grundmann, H., Grăser, Y., Schönian, G. \& Daschner, F. D. (1994). Randomly primed polymerase chain reaction yields comparable results to restriction fragment analysis in typing of Pseudomonas aeruginosa. Med Microbiol Lett 3, 42-48.

Grundmann, H., Schneider, C., Hartung, D., Daschner, F. D. \& Pitt T. L. (1995). Discriminatory power of three DNA-based typing techniques for Pseudomonas aeruginosa. J Clin Microbiol 33, 528-534.

International Pseudomonas aeruginosa Typing Study Group (1994). A multicenter comparison of methods for typing strains of Pseudomonas aeruginosa predominantly from patients with cystic fibrosis. J Infect Dis 169, 134-142.

Joys, T. M. \& Kim, H. (1978). Identification of the $\varepsilon-\mathrm{N}$-methyllysine residues in the phase-1 flagellar protein of Salmonella typhimurium. Microbios Lett 76, 65-68.

Kelly-Wintenberg, K. \& Montie, T. C. (1989). Cloning and expression of Pseudomonas aeruginosa flagellin in Eschericbia coli. J Bacteriol 171, 6357-6362.

Kelly-Wintenberg, K., Anderson, T. \& Montie, T. C. (1990). Phosphorylated tyrosine in the flagellum filament protein of Pseudomonas aeruginosa. J Bacteriol 172, 5135-5139.

Kelly-Wintenberg, K., South, S. L. \& Montie, T. C. (1993). Tyrosine phosphate in a- and b-type flagellins of Pseudomonas aeruginosa. J Bacteriol 175, 2458-2461.
Logan, S. M., Trust, T. J. \& Guerry, P. (1989). Evidence for posttranslational modification and gene duplication of Campylobacter flagellin. J Bacteriol 171, 3031-3038.

Masten, B. J. \& Joys, T. M. (1993). Molecular analyses of the Salmonella $g$ flagellar antigen complex. J Bacteriol 175, 5359-5365.

Morgan, J. A. W., Winstanley, C., Pickup, R. W. \& Saunders, J. R. (1991). Rapid immunocapture of Pseudomonas putida cells from lake water by using bacterial flagella. Appl Environ Microbiol 57, 503-509.

Oyofo, B. A. \& Rollins, D. M. (1993). Efficacy of filter types for detecting Campylobacter jejuni and Campylobacter coli in environmental water samples by polymerase chain reaction. Appl Environ Microbiol 59, 4090-4095.

Picard, B., Denamur, E., Barakat, A., Elion, J. \& Goullet, P. (1994). Genetic heterogeneity of Pseudomonas aeruginosa clinical isolates revealed by esterase electrophoretic polymorphism and restriction fragment length polymorphism of the ribosomal RNA gene region. J Med Microbiol 40, 313-322.

Schleifer, K. H. (1994). Phylogeny and in situ detection of Pseudomonas. In 128th Meeting of the Society for General Microbiology (Abstracts), p. 21, Cambridge.

Schoenhals, G. \& Whitfield, C. (1993). Comparative analysis of flagellin sequences from Escherichia coli strains possessing serologically distinct flagellar filaments with a shared complex surface pattern. J Bacteriol 175, 5395-5402.

Totten, P. A. \& Lory, S. (1990). Characterization of a type a flagellin gene from Pseudomonas aeruginosa.J Bacteriol 172, 7188-7199.

Wieland, F., Paul, G. \& Sumper, M. (1985). Halobacterial flagellins are sulfated glycoproteins. J Biol Chem 260, 15180-15185.

Winstanley, C., Morgan, J. A. W., Pickup, R. W. \& Saunders, J. R. (1994). Molecular cloning of two Pseudomonas flagellin genes and basal body structural genes. Microbiology 140, 2019-2031.

Received 4 October 1995; revised 22 March 1996; accepted 28 March 1996. 